\title{
PARTNERSHIP
}

The Canadian Journal of Library and Information Practice and Research

Revue canadienne de la pratique et de la recherche en bibliothéconomie et sciences de linformation

vol. 16 , no. $2(2021)$

Features (editorially reviewed)

DOI: https://dx.doi.org/10.21083/partnership.v16i2.6382

CC BY-NC-ND 4.0

\section{Transforming Your Conference Presentation into a Journal Article}

\section{Transformer sa présentation de congrès en article de revue}

\author{
Katya C. MacDonald \\ Research Facilitator \\ University of Saskatchewan Library
}

\section{Abstract / Résumé}

In many disciplines, most conference presentations end when the conference does; they do not go on to become peer-reviewed articles. Yet there is also research to suggest that continuing to work with a conference paper to turn it into an article leads to higher research productivity overall, with additional benefits of increasing a researcher's confidence, motivation, and capacity for further research (Lee \& Boud, 2003).

This article was itself once a conference presentation or, more precisely, a workshop entitled Transforming Your Conference Paper into a Journal Article developed for the University of Saskatchewan and the Saskatchewan Library Association member librarians, and presented to researchers and writers from diverse disciplines. At those presentations attendees asked whether I would be turning this presentation into an article - a very meta question that did indeed seem like a logical next step! Synthesizing multidisciplinary scholarship on academic writing, resources from academic writing coaches, and case studies, this piece is intended to be a DIY workshop focusing on concrete strategies for addressing major barriers in the conference paper-to-article editing process.

Dans de nombreux domaines, la plupart des présentations offertes lors de congrès se terminent quand le congrès finit; elles ne deviennent pas des articles évalués par les pairs. Pourtant, des études suggèrent que le fait de continuer à travailler sur un document de congrès afin de la transformer en article mène à une augmentation générale de la productivité de la recherche accompagnée d'avantages supplémentaires 
liés à une hausse de confiance, de motivation et de capacité du chercheur à poursuivre sa recherche (Lee et Boud, 2003).

Cet article a d'abord été une présentation ou, plus précisément, un atelier intitulé « Transformer sa présentation de congrès en article de revue » qui avait été développé pour l'Université de la Saskatchewan et pour les membres bibliothécaires de la Saskatchewan Library Association, et présenté à des chercheurs et des écrivains de diverses disciplines. Durant ces présentations, les participants me demandaient si j'allais rédiger un article à partir de l'atelier - une question très « méta » qui semblait être, en fait, très logique comme prochaine étape. En offrant une synthèse des études multidisciplinaires sur la rédaction universitaire, des ressources provenant de formateurs en rédaction universitaire et des études de cas, cet article se veut un atelier pratique misant sur des stratégies concrètes permettant de surmonter les principaux obstacles du processus de transformation d'une présentation de congrès à un article de revue.

\section{Keywords / Mots-clés}

academic writing, conference presentations, publishing, journal articles, editing; travaux universitaires, présentations de congrès, publication, articles de revues, rédaction

\section{Why turn a conference paper into a journal article?}

Across many disciplines a researcher produces a much higher volume of conference papers compared with journal articles. One nursing conference, for instance, tracked presentations at the conference and found that about $30 \%$ were later submitted for publication (Levett-Jones \& Stone, 2012). But publishing an article that is based on a previous conference presentation can lead to higher research productivity overall (Lee \& Boud, 2003), meaning that the value of the process goes beyond simply producing another publication. These articles expand the researcher's connections to a broader community of knowledge, creating conversation, new ideas, and more robust collaborations, all of which tend to energize the research process.

In the midst of COVID-19 conference and travel cancellations, many people have prepared presentations but are left with nowhere to present or discuss them with others. Creating a journal article out of these planned presentations offers a way to contribute to scholarly conversations at a time when they cannot happen in person.

\section{Why don't people do this more often?}

Two key barriers that writers and writing coaches alike often identify are a lack of time, and a lack of a sufficiently detailed structure or plan for completing the article (VanEvery, 2013). For most people, the amount of time available is not wholly within our control; instead, we can create a timeline for writing that helps maximize our resources. 


\section{Strategies to address barriers}

This short overview of the conference paper-to-journal-article process begins by walking through the major changes that typically need to be made during the editing process. Next, case studies and examples show how the introduction of a conference paper can be used as a "to-do list" for constructing an editing plan, in which researchers' potential audiences and scholarly goals serve as two bases for decision-making. Finally, I share planning sheets, developed specifically for this topic, that draw all of these considerations together and allow readers to move forward with a basic outline of next steps for their own conference papers.

These strategies are focused on styles and structures of writing that are most typical of the social sciences and humanities, but identifying the differences in audiences and goals for conferences and articles can be a useful editing exercise in any discipline. For a more in-depth analysis of what the conference presentation-to-journal-article process can look like in a scientific discipline, see Gravey (2016) and Montesi and Owen (2008).

\section{Before the conference (writing a new conference paper to facilitate future publication)}

As you prepare your conference presentation, consider flagging places in the paper that will later need attention to become a journal article. In particular, you may wish to note two things: whether the conference and journal have differing audiences as well as what goals you have for presenting at the conference and publishing in the journal.

Audiences and goals are two big factors that influence the specific content and structure of writing, so identifying them explicitly from the outset sets the stage for creating a structure for your writing later on: a way to address one of the barriers to creating an article from a conference presentation.

Additionally, you can note where you are omitting material to suit the constraints of a conference time slot. Do you want to add additional context or explanation later? Is additional evidence available or necessary? What bodies of literature do you intend to engage with more thoroughly? Can your notes and PowerPoint slides do double duty as an outline for your future paper? Putting together presentation slides is often a process of distilling key points for audience members and filling in necessary background knowledge. In that way, your slides can help you articulate what needs to be added in writing (rather than the visual format of the slides) to the eventual journal article.

\section{After the conference (adapting an existing conference paper)}

But what if you prepared a conference presentation at some point in the past that you think would make a valuable journal article? It is at this stage that the barriers to creating the article become most evident. Some reflection on your audience and goals at the outset can help to establish a structure and timeline for writing. 
Comparing the differing intentions of conference presentations and journal articles is a way to identify areas that require changes from which you can create an itemized editing plan.

\section{Table 1}

Comparing intentions of conference presentations and journal articles

\begin{tabular}{|c|c|}
\hline Conference presentations may be... & Journal articles may be... \\
\hline $\begin{array}{ll}\text { - } & \text { Descriptive } \\
\text { - } & \text { Preliminary/brief } \\
\text { - } & \text { Focused on research process } \\
\end{array}$ & $\begin{array}{l}\text { - In depth (especially re: background, } \\
\text { context, existing literature) } \\
\text { - Focused on argument } \\
\text { - } \text { Definitive in tone } \\
\text { - Tailored to specific stylistic/format } \\
\text { specifications of a journal }\end{array}$ \\
\hline
\end{tabular}

Within these general considerations, there are several key areas that typically require the most attention and will also provide the most guidance when establishing a plan for creating the journal article:

- Introductions and conclusions

- Jargon, terminology, and relevance of language

- Audience

- Context for content and arguments

Introductions, setup, and conclusions are often abbreviated for a conference presentation and may refer to work that is currently in progress. By contrast, a journal article expands and elaborates, often in ways that bring the content closer into alignment with the conventions of the journal and the discipline.

Audience, too, may shape the type of content that is presented at a conference or in a journal article. A conference may be more focused than a journal article, since attendees are likely to be people with an existing interest or background in the specific topic. The audience is also more clearly identifiable-they may be people whose work you know, and you may choose to adapt your presentation on the fly based on your observations and interactions with your audience. Of course, little of this is possible in a journal publication. All of these differences mean that in a journal article, written introductions and conclusions provide not only important content, but establish important relationships with the reader as well. Introductions therefore present opportunities to create a plan for the editing process.

\section{Making an editing plan: worksheet}

The two templates below ask open-ended questions whose answers will help you to identify areas of your conference presentation that will need revision to become a journal article and from there create an editing plan and structure. The Planning and Framing sheet helps to identify the changes that need to be made. The Evaluating 
Content and Format sheet delves deeper to identify strategies that you can use to bring the nuance and expansion needed for the journal article. They ask you consider what you hope your article does, not only what it says.

\section{Table 2}

Planning and Framing Worksheet

\begin{tabular}{|l|l|}
\hline Questions \\
\hline $\begin{array}{l}\text { Who is the audience } \\
\text { of the conference } \\
\text { paper? (Consider } \\
\text { their probable } \\
\text { affiliation, expertise, } \\
\text { reasons for } \\
\text { attending your } \\
\text { conference panel...) }\end{array}$ \\
\hline $\begin{array}{l}\text { Who is the audience } \\
\text { of the journal article? } \\
\text { (Is it broader or } \\
\text { narrower than the } \\
\text { conference } \\
\text { audience? What } \\
\text { might be their goals } \\
\text { for reading the } \\
\text { journal?) }\end{array}$ \\
\hline $\begin{array}{l}\text { What are your goals } \\
\text { for writing/presenting } \\
\text { the conference } \\
\text { paper? }\end{array}$ \\
\hline $\begin{array}{l}\text { What are your goals } \\
\text { for writing/publishing } \\
\text { the journal article? }\end{array}$ & \\
\hline $\begin{array}{l}\text { What do you hope } \\
\text { readers will take } \\
\text { away from the } \\
\text { paper? }\end{array}$ & \\
\hline $\begin{array}{l}\text { What questions or } \\
\text { feedback have you } \\
\text { had on your paper } \\
\text { thus far? }\end{array}$ & \\
\hline
\end{tabular}




\section{Table 3}

Evaluating Content and Format Worksheet

\begin{tabular}{|l|l|}
\hline Questions \\
\hline $\begin{array}{l}\text { What are the key } \\
\text { assertions or } \\
\text { contributions of your } \\
\text { paper? }\end{array}$ \\
\hline $\begin{array}{l}\text { What evidence do } \\
\text { you employ? }\end{array}$ \\
\hline $\begin{array}{l}\text { What context do } \\
\text { readers need to } \\
\text { understand your key } \\
\text { assertions? What } \\
\text { terminology needs to } \\
\text { be explained? }\end{array}$ \\
\hline $\begin{array}{l}\text { How would you } \\
\text { describe your } \\
\text { research } \\
\text { methodology? }\end{array}$ \\
\hline $\begin{array}{l}\text { What bodies of } \\
\text { literature do you } \\
\text { respond/contribute } \\
\text { to? (Or: why do } \\
\text { readers need your } \\
\text { paper?) }\end{array}$ \\
\hline $\begin{array}{l}\text { What did you cut or } \\
\text { omit from your paper } \\
\text { to make it fit the } \\
\text { constraints of a } \\
\text { conference paper? } \\
\text { (Or: what else would } \\
\text { you like to say?) }\end{array}$ \\
\hline
\end{tabular}

\section{Where next from these reflections?}

Where does all this reflection about audiences and goals take you next? They form the underlying structure for why we write the way we do and thinking about them explicitly helps to identify what needs to be added or changed when repurposing writing through 
editing. We can use these reflections to create a to-do list and address some of the common barriers to publishing a journal article from a conference paper.

\section{Strategies: introductions as launching points for an editing work plan}

Academic writing specialists often highlight the importance of the introduction as a tool for clarifying or creating structure in a paper (The Writing Center, 2021). More than sites of editing, though, introductions can serve as a basis for creating a timeline and structure for your editing. Focusing on the introduction and spending time there can help to reduce work and increase clarity later on.

This sample introductory paragraph comes from a piece of my writing that began as a conference presentation at a national disciplinary conference for historians in Canada and eventually became a published peer-reviewed article. Here, I will trace the evolution of the paragraph and highlight how coming back to the introductory paragraph helped to create a to-do list to refine the structure and clarity of the entire article.

Here is the original paragraph from the conference presentation:

Speaking recently with Tla'amin (Sliammon) community members about histories of handmade items, it became apparent in our discussions that in the processes of making and interpreting these objects' historical significance, the tools that created the items occupied a background role. Yet tools and social connections have worked together to create not only objects themselves, but also their historical significance. They have also helped to construct change, in direct opposition to colonial forces seeking to limit Aboriginal people's identities: tools have become historical sources and actors in and of themselves. As a result, I see this paper as a methodological reflection on crafters' tools as historians' tools as well.

Each of these highlighted items represents an area where revision is needed to give these sentences context and clarity for article readers who would not have access to visuals and in-person discussion as they would at a conference. Having identified these areas, I can now add them to my to-do list:

1. Speaking recently with Tla'amin (Sliammon) community members about histories of handmade items

- Why was I speaking to community members? In what context? Who are the Tla'amin people?

o These questions were answered in part by the accompanying conference slides, which can become explanatory sentences or footnotes in the article

- To-do list:

o explain my methodologies and the background for the research explicitly

o position myself within the research (a disciplinary convention in the field of history; other disciplines will have other conventions, but in 
general this step is about explaining how this research fits within larger bodies of scholarship)

o identify influential bodies of scholarship that helped me connect my decisions about methodologies to the arguments I made

2. the tools that created the items occupied a background role

- As opposed to the foreground role of other objects? According to whom?

- To-do list:

o contextualize my research within larger bodies of scholarship

3. Yet tools and social connections have worked together to create not only objects themselves, but also their historical significance

- Is this my argument or a description of my research for the audience?

What evidence and explanations do I have to connect tools and social connections?

- To-do list:

o articulate argument strongly and scan paper for directly relevant evidence that I can use to reinforce the argument when I expand the conference presentation into a full article

\section{Aboriginal}

- To-do list:

o terminology change - "Indigenous" is a more appropriate term; it also more closely reflects my intentions and values for my scholarship and matches the journal's usage

- Reflects new knowledge and perspectives gained since the conference paper was written

5. (and 6) tools have become historical sources and actors in and of themselves and a methodological reflection on crafters' tools as historians' tools as well

- Do these sentences reflect the main argument? Or is this another methodological discussion? What is my primary focus?

- To-do list:

o refer to revised argument and incorporate these points into methodology section instead

Synthesizing the above to-do list items, I found three key areas needing further attention:

- Context and background

- Engagement with existing literature and articulating my contributions to the field

- Distinguishing between argument vs. methodology

I addressed these issues in the introductory paragraph first to create a framework for revising and expanding the rest of the paper. By the time the article was submitted to the journal, it had gained some explanation about my role as a researcher, along with a clearer focus for the rest of the paper. Peer reviewers suggested additional revisions, many of which pushed me to further refine the to-do list items I had already identified for myself. Comparing the three versions of the introductory paragraph side by side, it is 
possible to see how journal articles add specificity, nuance, and detail to a more general and informal conference presentation.

\section{Table 4}

Comparison of the three versions of the introductory paragraph side by side

\section{Conference introduction}

Speaking recently with Tla'amin (Sliammon) community members about histories of handmade items, it became apparent in our discussions that in the processes of making and interpreting these objects' historical significance, the tools that created the items occupied a background role. Yet tools and social connections have worked together to create not only objects themselves, but also their historical significance. They have also helped to construct change, in direct opposition to colonial forces seeking to limit Aboriginal people's identities: tools have become historical sources and actors in and of themselves. As a result, I see this paper as a methodological reflection on crafters' tools as historians' tools as well.

\section{Article introduction (before peer review)}

In 2012, when I first visited Sliammon, a small First Nation on the west coast of British Columbia near the city of Powell River, as a PhD student hoping to gain a sense of whether community members would be interested in working with me on an oral history dissertation project, I spoke with Tla'amin (Sliammon) community members about "histories of handmade items." It became apparent in our discussions that in the processes of making and interpreting these objects' historical significance, the tools that created the items occupied a background role. Yet tools and social connections have worked together to create not only objects themselves, but also their historical significance. They have also helped to construct change, in direct opposition to colonial forces seeking to limit Indigenous people's identities.

\section{Article introduction (published)}

I first visited Sliammon, a small First Nation on the west coast of British Columbia near the city of Powell River, in 2012. As a PhD student, I hoped to learn whether community members would be interested in working with me on an oral history project about histories of handmade items. I spoke with Tla'amin (Sliammon) community members about making and interpreting objects of historical significance. In our conversations, they made it clear that the tools used to create significant items occupied a background role. The tools sat in private, in contrast to the more public popularity of carvings, baskets, and other items that have seen growing community and commercial appeal over the course of the twentieth and twenty-first centuries. Despite their understated presence, tools and social connections have worked together to create objects and their historical significance. They have helped to construct change, in direct opposition to colonial forces seeking to limit Indigenous people's identities. As revealed in community members' perspectives shared in oral histories, histories of tools illuminate labor and gender histories, as well as histories of local resistance to colonialism. ${ }^{1}$

\footnotetext{
1 This paragraph was originally published in MacDonald, K.C. (2020). A Spindle, an awl, and the construction tools of Tla'amin histories in the twentieth century. Native American and Indigenous Studies, 7(1), 3-35.
} 
The most immediate difference among the three introductions is how each one grows in length-or more precisely, in detail, specificity, and nuance. Thinking of introductions as a microcosm of the paper as a whole, they provide insights into the specific changes that need to occur when transforming a piece of writing from a conference presentation to a journal article. Introductions can therefore offer one response to the barriers identified at the beginning of this piece: the lack of a structure or plan for taking the step from conference presentation to journal article.

My aim in putting together these resources has been to offer some structures and resources for the conference presentation-to-journal-article transformation process: a process with several long-term benefits for research and future collaborations, but also a process where it is easy to get lost in the weeds and lose sight of the larger goals for the writing. Particularly now, when so many aspects of scholarly conversations have taken on new forms in the digital world, there exist promising opportunity to build on these conversations by bringing conference research to new light in journal articles.

\section{References}

Lee, A., \& Boud, D. (2003). Writing groups, change and academic identity: Research development as local practice. Studies in Higher Education, 28(2), 187-200.

Levett-Jones, T., \& Stone, T. (2012). Writing for publication: Turning the conference paper into publishable work. In K. Holland \& R. Watson (Eds.), Writing for publication in nursing and healthcare (pp. 145-161). John Wiley \& Sons, Ltd.

VanEvery, J. (2013, June 4). From conference presentation to journal article. Jo VanEvery.

Gravey, V. (2016, May 9). Publication: From student forum paper to journal article. Crossroads Europe.

Montesi, M., \& Owen, J. M. (2008). From conference to journal publication: How conference papers in software engineering are extended for publication in journals. Journal of the American Society for Information Science and Technology, 59(5), 816-829.

The Writing Center. (2021). Writing exercises. 


\section{Additional Resources}

Belcher, W. L. (2009). Reflections on ten years of teaching writing for publication to graduate students and junior faculty. Journal of Scholarly Publishing, 40(2), 184199.

Burstein, M. (2014, November 9). Turning conference papers into articles. The Little Professor.

Cayley, R. (2011, February 9). Reverse outlines. Explorations of Style.

Medical Library Association. (n.d.). How to convert an oral presentation to a manuscript.

Theys, S. (2016, March 16). Things to remember when transforming your conference paper into a journal article. Politics Blog.

Thomson, P. (2016, June 6). From conference paper to journal article - writing in small chunks. Patter. 